\title{
ELEVENTH ANNUAL NESTBOX REPORT OF THE BRANDON JUNIOR BIRDERS
}

\section{by J. Lane, 1701 Lorne Avenue and D. Knock, 260 20th Street, Brandon}

During 1971 our club reached the 3000 mark in nestboxes built and set out, but we estimate 200 of these are no longer habitable. Our total nestline mileage exceeds 700 miles, all but 60 miles being in southwest Manitoba, the balance in Saskatchewan. We plan to have another 200 boxes or more built and set out by next spring.

Our club has several notable items to report from the 1971 season. First of all, our farthest-west record for nesting Eastern Bluebirds was extended from Virden, Manitoba, to just west of Whitewood, Saskatchewan, 70 miles west of the previous record. Our total nestings of bluebirds exceeded 600 for the first time. During the 1970 season we had found three cases of Tree Swallows' nests with the egg clutches including two or more bluebird eggs; all three nestings were failures, as was a fourth example found in 1971, but a fifth instance, with just one bluebird egg present in the clutch, proved successful, a Mountain Bluebird fledging $a^{\prime}$ 'ong with the swallows' own brood. Red Squirrels occupied no less than ten of our nestboxes, a big jump from the one a year previously reported; in some cases they did some renovating, such as enlarging the nesthole.
Examples of cross-breeding continue to appear on our nestlines. In 1970 we listed two instances of male Eastern Bluebirds and female Mountain Bluebirds raising families, the first in a nestbox just north of Kenton, Manitoba, the other east of Carberry, Manitoba. In 1971 three additional cases of cross-breeding were found: a male hybrid X Eastern; male Mountain X female Eastern; and a male Eastern X female Mountain. These three matings produced one, four, and three young respectively. A total of six young from these nests are now with Dr. D. Krieg at State University, New Paltz, New York; all six have undergone their post-juvenile molt, and all appear to be hybrids.

In 1970 we reported the banding of over 1600 bluebirds of the two species; in 1971 the total bandings were 2632, of which 450 were Eastern Bluebirds. Our total nestings for the year follow: Mountain Bluebird (first-broods) 508 Eastern Bluebird (first-brood).... 135

Cross-bred nestings.....

Tree Swallows (estimate)........... 1400

House Wrens ................................ 38

Starlings …….......................... 12

Deer Mice …............................. 45

Red Squirrels ............................ 10

\section{ANNUAL REPORT OF THE INDIAN HEAD BLUEBIRD TRAIL PROJECT, 197।}

by Lorne Scott, Indian Head

An additional 200 nest boxes were set out this spring on the Indian Head Bluebird Trail project, bringing the total number of houses set out since the project began in 1963 to 1200 . One hundred of these houses were set out south of Grenfell along highway \#47, going as far south as \#16, then west to Glenavon, and north along grid roads to Wolseley. Another trail of 50 houses was established from Balgonie to Fort Qu'Appelle along highway
\#10. A third trail was started along the grid road running north of White City, east of Regina.

In past years Tree Swallows occupied most of the new houses and Mountain Bluebirds did not increase in numbers on new trails until the second and third year. This year was no exception; Tree Swallows occupied about $90 \%$ of the new houses set out. Only eight houses were occupied by Mountain Bluebirds along the new trails. 
About 800 young Mountain Bluebirds were raised from approximately 200 nests this spring. This is an increase of about 45 nests from last year. Banding was continued under a permit from the Canadian Wildlife Service. Of the 700 Mountain Bluebirds banded, 64 were adult females, two were adult males, and the rest were nestlings. Of the 1,000 Mountain Bluebirds banded in 1969 and 1970, 17 adult females were recaught this spring while nesting.

Tree Swallows occupied about 450 nests and produced over 2000 young. This is an increase of 125 nests over last year. Twenty-eight adult females were recaught this year out of the 1450 Tree Swallows banded in 1969 and 1970. Another 1450 Tree Swallows were banded this year, of which 180 were adults, largely famales.

Unfortunately House Sparrows seem to be on the increase, especially on trails which have been established for two or three years. Several Tree Swallows and Mountain Bluebirds were found dead in the bottom of nest boxes beneath sparrow nests. In fact, onf nest box contained two dead adult Tree Swallows and one adult male Mountain Bluebird under a sparrow nest.

Perhaps to show more clearly the takeover of nest boxes by House Sparrows, we can use the bluebird trail from Wolseley to Melville for an example. This trail contained 100 houses when set up in 1969. The following chart illustrates the number of nests used by the species.

Year

$$
1969
$$

Tree Swallows 73

Mountain Bluebird .... 12

41

Eastern Bluebird

House Sparrow

1

Total houses

$$
\text { destroyed }
$$

1971

Several interesting observations were again made this year. One of these was a male Eastern Bluebird assisting a female Mountain Bluebird in raising her family. This was reported in the Blue Jay (29:126-127). One Tree Swallow nest contained $11 \mathrm{eggs}$; all the eggs hatched and the 11 young were successfully fledged. Another Tree Swallow nest was checked in early July just before the young were able to fly. The nest contained three normally colored young and one almost complete albino. This dilute albino was all white below and a very light tan color on the top of its head, back and wings. It appeared to be as healthy and strong as the other three young Tree Swallows.

The nest boxes are visited at least four times a year. The first visit is made in mid-May; on this trip the number of bluebird and Tree Swallow nests can be determined. About 30\% of the adult female bluebirds are caught while incubating their eggs and banded. The second trip is made in early June. The young bluebirds are old enough to band, and about $50 \%$ of the adult Tree Swallows are caught on their nests and banded. The third trip is carried out in late June or early July to band the young Tree Swallows. The final trip takes place in the fall to clean out the old nests and repair the houses. Each complete trip takes from two to three days, and covers a distance of about 500 miles.

The following map shows the present location of the Indian Head Bluebird Trails.

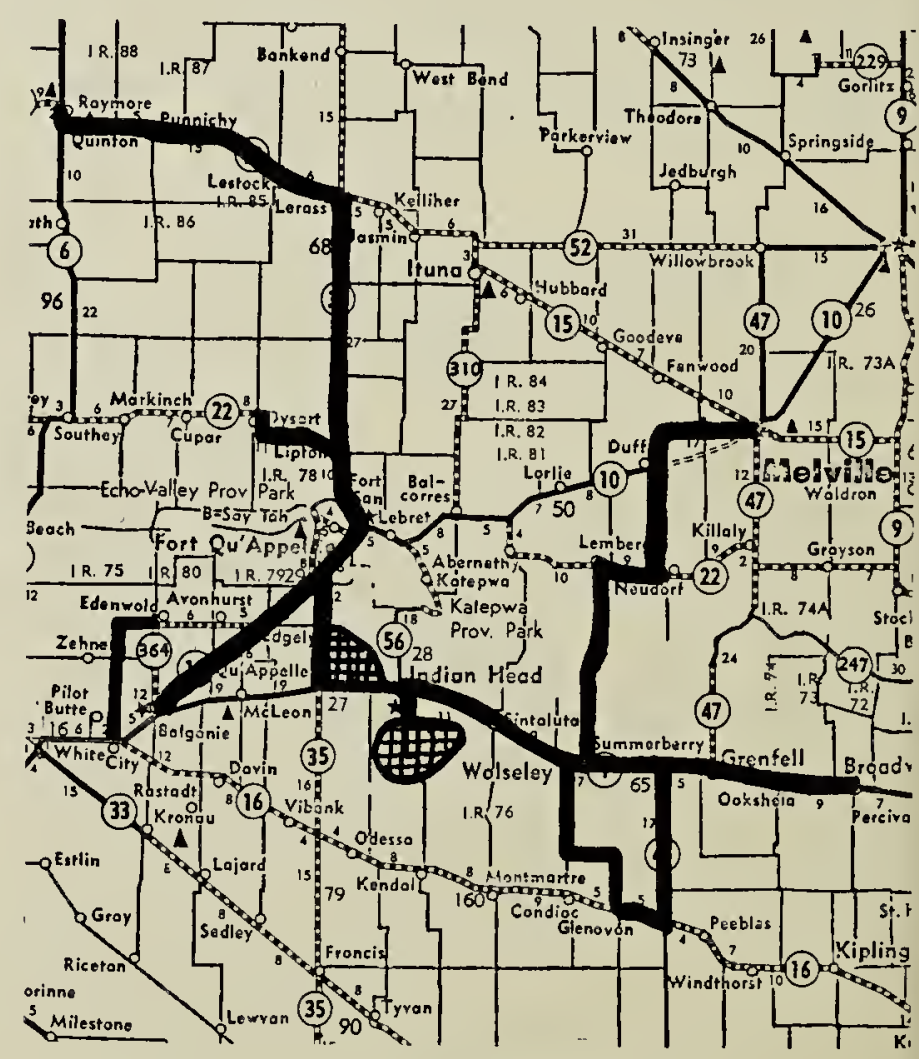

Indian Head Bluebird Trails 